Jurnal Media Komunikasi Pendidikan Pancasila dan Kewarganegaraan

Volume 2, Nomor 1 April 2020

\title{
PELAKSANAAN PROGRAM BANTUAN PANGAN NON TUNAI (BPNT) BERDASARKAN PERMENSOS RI NO. 20 TAHUN 2019 TENTANG PENYALURAN BANTUAN PANGAN NON TUNAI DI DESA KARANGANYAR KECAMATAN KALIBENING KABUPATEN BANJARNEGARA
}

\author{
Adinda Syifa Dinarila Balqis \\ Fakultas Hukum, Universitas Wijayakusuma Purwokerto \\ Iskatrinah \\ Fakultas Hukum, Universitas Wijayakusuma Purwokerto \\ Wahyu Hariadi \\ Fakultas Hukum, Universitas Wijayakusuma Purwokerto
}

\begin{abstract}
Indonesia is one of the many developing countries in the world. Indonesia also a country that upholds the principle of "welfare state", where the state has the principle of being a welfare state. With the predicate of "welfare state", Indonesian government strives for various programs to improving the welfare of its people. So the government took the policy of issuing social assistance programs in the form of rice to the people in poor category. The program continues to be upgrade from the original name of poor rice (RASKIN) become prosperous rice (RASTRA) and the latest is Non-Cash Food Assistance (BPNT). The program is regulated in Permensos No. 20 of 2019 concerning Distribution of Non-Cash Food Aid. In order to find out how the program was implemented, the writer used a Normative juridical approach, with clinical legal research specifications. The method of presenting data is presented in the form of groupings and then systematically arranged. Conclusion: Based on the discussion of the results of the study, it can be concluded: -The implementation of the Non-Cash Food Assistance program in Karanganyar Village, Kalibening District, Banjarnegara patent district has not been carried out in accordance with Law of the Republic of Indonesia Number 13 of 2011 concerning Handling of the Poor and Regulation of the Ministry of Social Affairs of the Republic of Indonesia Number 20 of 2019 concerning the Distribution of Non-Cash Food Aid and Guidelines for the Implementation of Non-Cash Food Aid in 2019. In the validation process in 2019 there is still data from the Data and Information Center on the Integrated Database for Poor Poor Handling that is not in accordance with the conditions in the field, resulting in data This is not yet right on the list of potential recipients of beneficiary families.
\end{abstract}

Keywords: Implementation, Poor Rice, Non-Cash Food Aid.

\begin{abstract}
Abstrak
Negara Indonesia merupakan salah satu dari sekian banyak negara berkembang di dunia. Indonesia juga merupakan negara yang menjunjung tinggi prinsip welfare state, dimana negara memiliki prinsip sebagai negara kesejahteraan. Dengan predikat negara kesejahteraan tersebut maka pemerintah Indonesia mengupayakan berbagai program yang bertujuan untuk meningkatkan kesejahteraan masyarakatnya. Sehingga pemerintah mengambil kebijakan mengeluarkan program bantuan sosial yang berupa beras kepada
\end{abstract}


masyarakat dengan kategori fakir miskin. Program tersebut terus diperbaiki dari semula bernama beras miskin (RASKIN) menjadi beras sejahtera (RASTRA) dan yang terbaru saat ini adalah Bantuan Pangan Non Tunai (BPNT). Program tersebut diatur dalam Permensos No 20 Tahun 2019 tentang Penyaluran Bantuan Pangan Non Tunai. Untuk mengetahui bagaimana pelaksanaan program tersebut, penulis menggunakan metode pendekatan secara Yuridis Normatif, dengan spesifikasi penelitian clinical legal research. Metode penyajian data disajikan dalam bentuk uraian-uraian yang dikelompokkan dan kemudian disusun secara sistematis. Kesimpulan : Berasarkan pembahasan terhadap hasil penelitian, maka dapat disimpulkan : -Pelaksanaan program Bantuan Pangan Non Tunai di Desa Karanganyar Kecamatan Kalibening Kabupaten Banjarnegara belum dilaksanakan sesuai dengan Undang - Undang Republik Indonesia Nomor 13 Tahun 2011 tentang Penanganan Fakir Miskin dan Peraturan Kementerian Sosial Republik Indonesia Nomor 20 Tahun 2019 tentang Penyaluran Bantuan Pangan Non Tunai serta Pedoman Pelaksanaan Bantuan Pangan Non Tunai Tahun 2019. Dalam proses validasi di tahun 2019 masih terdapat data dari Pusat Data dan Informasi tentang Basis Data Terpadu Penanganan Fakir Miskin yang tidak sesuai dengan kondisi dilapangan sehingga mengakibatkan data tersebut belum tepat sasaran terhadap calon peseta keluarga penerima manfaat.

Kata Kunci: Pelaksanaan, Beras Miskin, Bantuan Pangan Non Tunai.

\section{Pendahuluan}

Indonesia merupakan salah satu dari sekian banyak negara berkembang yang ada di dunia. Saat ini, Indonesia sedang gencar dalam berupaya mencapai tujuan dasar dari negara Indonesia itu sendiri yaitu untuk melindungi segenap bangsa Indonesia dan seluruh tumpah darah Indonesia dan untuk memajukan kesejahteraan umum, mencerdaskan kehidupan bangsa dan ikut melaksanakan ketertiban dunia yang berdasarkan kemerdekaan, perdamaian abadi dan keadilan sosial. ${ }^{1}$

Indonesia juga merupakan negara yang menjunjung tinggi prinsip welfare state, dimana negara memiliki prinsip sebagai negara kesejahteraan, konsep ini muncul menggantikan konsep legal state atau negara penjaga malam. ${ }^{2}$ Pemerintah sebagai alat negara yang memiliki kewajiban untuk menyejahterakan warga masyarakatnya. Dengan predikat

1 Redaksi Sinar Grafika, "UUD 1945 Hasil Amandemen \& Proses Amandemen UUD 1945 Secara Lengkap“(Jakarta: Sinar Grafika, 2016), hlm.3 kewajiban untuk menyejahterakan warga Indonesia itu, maka pemerintah akan selalu mengupayakan kesejahteraan untuk warga negara negara Indonesia dengan berbagai cara. Hal tersebut mendorong lahirnya kebijakan-kebijakan yang dengan kata lain disebut freies ermessen.

Kebijakan-kebijakan yang muncul tentunya masih akan terus berkembang. Ada kebijakan yang terus dipertahankan, ada kebijakan yang dihapuskan, dan ada pula kebijakan yang masih dipertahankan namun tetap dikembangkan. Hal yang demikian terjadi karenakan dinamika masyarakatyang berkembang sangat pesat. Baik dalam segi sosial maupun ekonomi, maka pemerintah harus terus mengikuti perkembangan masyarakat namun terus berusaha membuat kebijakan-kebijakan yang relevan dan

2 Ridwan HR, "Hukum Administrasi Negara", (Jakarta : PT. Raja Grafindo Persada, 2007), hlm. 14 
tepat manfaat bagi warga negara Indonesia.

Dewasa ini pemerintah Indonesia sedang menghadapi situasi dimana mereka berkewajiban mengentaskan warga Indonesia dari sebuah keadaan yang disebut kemiskinan. Kemiskinan dalam hal ini diartikan bahwa masih banyak masyarakat Indonesia yang belum mampu memenuhi hak-hak dasarnya. Masalah kemiskinan di Indonesia bukan merupakan masalah baru. Bahkan masalah kemiskinan itu telah menjadi topik pembicaraan pemerintah kolonial Belanda sejak permulaan abad ini, ketika pemerintah kolonial Belanda meluncurkan suatu program anti kemiskinan yang dikenal dengan politik etis. Sesudah Indonesia merdeka, Orde Lama, Orde Baru dan Era Reformasi. Meskipun masalah kemiskinan telah lama hidup di tengahtengah bangsa Indonesia dan telah lama pula diupayakan untuk dihapuskan namun kemiskinan itu tetap ada, hidup bersama bangsa ini. ${ }^{3}$

Kebijakan pertama yang diambil oleh pemerintah guna memenuhi pangan, dalam hal ini "beras" maka pemerintah membuat program pembagian jatah beras miskin. Krisis moneter tahun 1998 menjadi awal pelaksanaan program Beras Miskin(RASKIN) yang bertujuan untuk memperkuat ketahanan pangan rumah tangga terutama rumah tangga miskin. Pada awalnya disebut program Operasi Pasar Khusus (OPK), kemudian diubah menjadi RASKIN mulai tahun 2002, RASKIN diperluas fungsinya tidak lagi menjadi program darurat (social safety net) melainkan sebagai bagian dari program perlindungan sosial masyarakat. Melalui sebuah kajian

3 Loekman Soetrisno, "Kemiskinan dan Kesenjangan di Indonesia”, Terj. Awan Setya Dewanta dkk. (Yogyakarta : Aditya Media, 1995), hlm 17 ilmiah, penamaan RASKIN menjadi nama program diharapkan akan menjadi lebih tepat sasaran dan mencapai tujuan RASKIN. $^{4}$

Namun program tersebut tidak sepenuhnya berhasil, banyak kendala seperti pendistribusian kualitas beras yang buruk dan ketidaktepatan sasaran penerima bantuan yang terjadi di program tersebut. Untuk mengikuti perkembangan kondisi tidak tepatnya kualitas beras dan sasaran bantuan tersebut, tentu saja pemerintah sebagai alat negara membuat kebijakan dan melahirkan program baru yang disebut Beras Sejahtera (RASTRA). Yang pada prakteknya bukan lagi hanya ditujukan untuk masyarakat miskin, namun lebih pada peningkatan kesejahteraan bagi penerimanya yang harus memiliki Kartu Keluarga Sejahtera (KKS).

Setelah program tersebut berjalan dari tahun 2015 sampai 2019, nyatanya usaha pemerintah masih saja menimbulkan polemik di masyarakat luas. Utamanya adalah kesenjangan pada program bantuan dari pemerintah. Dari mulai data penerimanya hingga kualitas beras yang sampai di tangan penerima itu sendiri yang tidak sesuai dengan Pedoman Umum (PEDUM) Bantuan Sosial Beras Sejahtera. Ditemukannya banyak penerima yang seharusnya tidak menerima, dalam hal ini keluarga yang tingkat kesejahteraannya sudah dapat dikategorikan mampu justru menerima bantuan. Sementara keluarga yang kesejahteraannya berada di bawah ratarata tidak mendapat bantuan tersebut. Bahkan data yang turun dari dinas terkait masih sama saja dengan data lama yang sudah sering diperbaharui. Tentu saja pemerintah tidak tinggal diam, tahun 2007 pemerintah hadir dengan program

4 BULOG, "Sekilas RASKIN", diakses dari http://www.bulog.co.id/sekilas_raskin.php, pada tanggal 10 Oktober 2019 pukul 19:12. 
Jurnal Media Komunikasi Pendidikan Pancasila dan Kewarganegaraan

Volume 2, Nomor 1 April 2020

baru yang diatur dalam Peraturan Menteri Sosial Nomor 1 Tahun 2018 tentang Program Keluarga Harapan (Permensos 1/2018) yaitu Program Keluarga Harapan (PKH). Program PKH bertujuan membantu masyarakat, namun dengan catatan tidak ingin masyarakat penerima program tersebut bergantung pada bantuan yang diberikan pemerintah. Dengan kata lain pemerintah berusaha membuat masyarakat lebih mandiri dengan dana yang diberikan. Kemudian pada tahun 2019 ini pemerintah juga tetap mengupayakan kesejahteraan masyarakat tingkat bawah dengan mendukung program PKH dengan program barunya yaitu atau Bantuan Pangan Non Tunai (BPNT), yang didasarkan dengan Peraturan PresidenRepublik Indonesia Nomor 63 Tahun 2017 Tentang Penyaluran Bantuan Sosial Secara Non Tunai.

Berdasarkan data Badan Pusat Statistik (BPS), daerah Kabupaten Banjarnegara memiliki tingkat kemiskinan sebesar $17,18 \%$ tentu saja bantuan tersebut sangat dibutuhkan. ${ }^{5}$ Namun karena sumber daya manusia yang kurang mumpuni, maka Dinas Sosial Kabupaten Banjarnegara bekerjasama dengan menurunkan pendamping untuk mengawasi jalannya program tersebut. Hal tersebut terjadi juga di Desa Karanganyar Kecamatan Kalibening Kabupaten Banjarnegara. Oleh karena itu penulis tertarik untuk melakukan penelitian lebih lanjut terhadap pelaksanaan program Bantuan Pangan Non Tunai (BPNT) berdasarkan PERMENSOS RI NO. 20 Tahun 2019 Tentang Penyaluran Bantuan Pangan Non Tunai di Desa Karanganyar

5 Data Badan Pusat Statistik Kabupaten Banjarnegara Tahun 1996-2017

6 Soerjono Soekanto \& Sri Mamudji, "PenelitianHukum Normatif (Suatu Tinjauan
Kecamatan Kalibening Kabupaten Banjarnegara.

\section{Rumusan Masalah}

Berdasarkan latar belakang tersebut di atas, dapat dirumuskan permasalahan sebagai berikut :

1. Bagaimanakah pelaksanaan program Bantuan Pangan Non Tunai di Desa Karanganyar Kecamatan Kalibening Kabupaten Banjarnegara?

2. Apakah yang menjadi kendala dari pelaksanaan program Bantuan Pangan Non Tunai di Desa Karanganyar Kecamatan Kalibening Kabupaten Banjarnegara?

\section{Metodologi Penelitian}

Metode pendekatan yang digunakan adalah yuridis normative. yaitu penelitian hukum yang dilakukan dengan cara meneliti bahan pustaka atau data sekunder sebagai bahan dasar untuk diteliti dengan cara mengadakan penelusuran terhadap peraturanperaturan dan literatur-literatur yang berkaitan dengan permasalahan yang diteliti. ${ }^{6}$

\section{Spesifikasi Penelitian}

Spesifikasi yang digunakan adalah deskriptif analitis yaitu melakukan deskripsi terhadap hasil penelitian dengan data yang selengkap dan sedetail mungkin. Deskripsi dimaksudkan adalah terhadap data primer dan juga data sekunder yang berhubungan dengan pelaksanaan program Bantuan Pangan Non Tunai (BPNT) di Desa Karanganyar Kecamatan Kalibening Kabupaten Banjarnegara. Selanjutnya dilakukan analisis terhadap penelitian dengan ,menggunakan peraturan perundangundangan dan teori yang relevan.

Singkat)", (Jakarta: Rajawali Pers, 2001), hlm. 13-14. 
2. Materi Penelitian

Pelaksanaan program Bantuan Pangan Non Tunai dan kendalakendala yang muncul pada pelaksanaan program tersebut di Desa Karanganyar Kecamatan Kalibening Kabupaten Banjarnegara.

3. Lokasi Penelitian

Penelitian ini dilakukan di Kabupaten Banjarnegara dengan lokasi penelitian di Desa Karanganyar Kecamatan Kalibening dan Dinas Sosial Kabupaten Banjarnegara.

4. Sumber Data

Dalam penelitian ini, bahan atau materi penelitian diperoleh dari sumber data sebagai berikut :

a. Peraturan Perundang-undangan : Undang-Undang tentang Pelayanan Publik, Undang-Undang tentang Penanganan Fakir Miskin , UndangUndang tentang Pangan, Peraturanperaturan dan Lembaran Daerah yang berhubungan dengan objek penelitian.

b. Literatur : Buku-buku, Makalah, Jurnal, Majalah, dan Koran yang berhubungan dengan objek penelitian

c. Dan lain-lain yang mendukung sumber data : Observasi

5. Metode Pengumpulan Data

Untuk mendapat data yang akurat dan faktual, maka diperlukan data sekunder dan data primer.

a. Data sekunder adalah data yang diperoleh melalui bahan kepustakaan. ${ }^{7}$ Pengumpulan data ini dilakukan dengan studi atau penelitian kepustakaan (library researce) yaitu dengan mempelajari peraturan-peraturan, buku-buku yang berkaitan dengan penelitian. Data sekunder yang dikumpulkan terdiri dari bahan hukum primer dan bahan

Ronny Hanitijo Soemitro, Metode Penelitian Hukum dan Yurimetri, Jakarta : Ghalia, 1994, hlm. 11 hukum sekunder dan bahan hukum tersier.

b. Data primer adalah data yang diperoleh secara langsung dari objeknya. ${ }^{8}$ Data primer diperoleh atau dikumpulkan dengan studi lapangan (field researce) dengan cara wawancara. Wawancara mendalam (indepth interview) untuk memperoleh informasi yang dibutuhkan dengan cara tanya jawab sambil bertatap muka antara pewanwancara dengan narasumber atau orang yang diwawancarai menggunakan pedoman wawancara tidak terstruktur. Pencatatan (recording) dibutuhkan untuk mendukung indepth interview dan observasi ( pengamatan ) yang dilakukan. Alat pengamatan yang dibutuhkan dalam penelitian ini untuk memperoleh hasil dan gambaran data yang valid adalah alat tulis untuk mencatat, alat perekam dan kamera untuk mendokumentasikan secara audio visual.

6. Metode Penyajian Data

Data yang telah terkumpul melalui kegiatan pengumpulan data belum memberikan arti apapun bagi tujuan penelitian. Penelitian belum dapat ditarik kesimpulan bagi tujuan penelitiannya sebab data itu masih merupakan bahan mentah, sehingga diperlukan usaha untuk mengolahnya.

7. Metode Analisis Data

Metode analisis data kualitatif dalam penelitian ini dengan cara berfikir konstruksi logis konsisten. Data dianalisis dengan menggunakan metode content analisis, dengan memperlajari isi data, dikualifikasi berdasarkan konsep yang dirumuskan oleh peneliti kemudian disusun secara sistematis. Dalam model ini

J. Supranto, Metode Penelitian Hukum dan Statistik, Jakarta : PT Rineka Cipta, 2003, hlm. 2. 
diperlukan empat komponen berupa : pengumpulan data, reduksi data, display data dan pengambilan kesimpulan. Keempat proses ini merupakan siklus interaktif. ${ }^{9}$

\section{Hasil Dan Pembahasan}

\section{Penerima Bantuan Pangan Non} Tunai (BPNT)

Penerima Bantuan Pangan Non Tunai yang ada di Desa Karanganyar

Berikut alur penyaluran BPNT dari Kabupaten Banjarnegara ke KPM di Desa Karanganyar :

\begin{tabular}{c} 
1. Data BDT dicetak kemudian \\
dikirim ke Desa melalui petugas \\
pendamping yang ditugaskan \\
oleh DINSOS ke Desa terk ait \\
\hline
\end{tabular}

4. Petugas BPNT Desa menarik KKS pada KPM dan menggesek kartu di e-Warong desa Sirukun

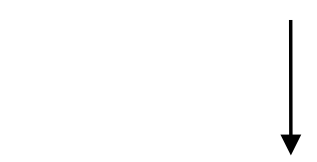

5. KPM datang ke kantor BUMDES untuk mengantri BPNT.

\section{Syarat Penerima Bantuan Pangan}

\section{Non Tunai}

Syarat Penerima BPNT sesuai Peraturan Menteri Sosial Republik Indonesia Nomor 20 Tahun 2019 tentang Penyaluran Bantuan Pangan Non Tunai tercantum dalam pasal berikut ${ }^{10}$ :

9 Burhan Bungin, Metodologi Penelitian Kualitatif, Jakarta : PT Raja Grafindo Persada 2005, hlm 70 .
Kecamatan Kalibening Kabupaten Banjarnegara adalah KK Miskin yang terdaftar sebagai Keluarga Penerima Manfaat (KPM). Data tersebut telah diolah dalam Basis Data Terpadu (BDT) melalui sensus kepemilikan harta benda dan kondisi keluarganya. Berikut jumlah penerima BPNT yang ada di Desa Karanganyar :
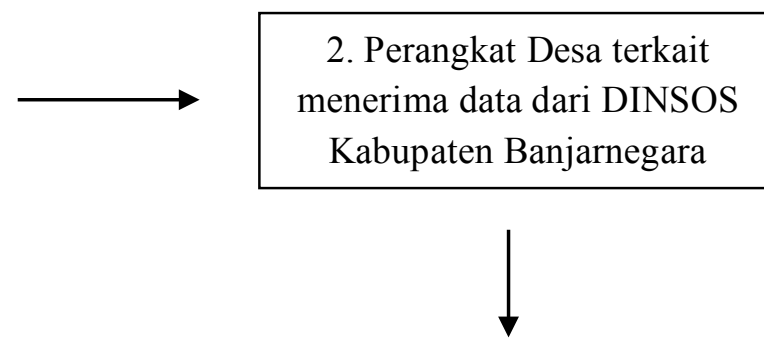

3. Perangkat Desa menyerahkan data ke pendamping dari

DINSOS untuk di eksekusi bersama dengan petugas BPNT yang ditugaskan di Desa

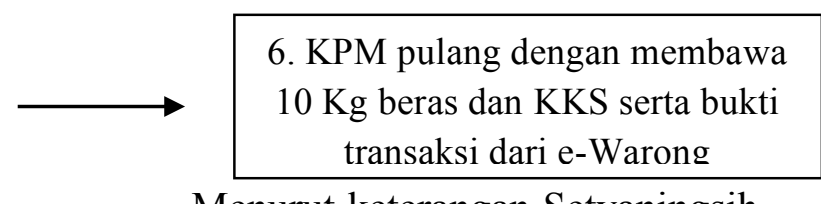

Menurut keterangan Setyaningsih, selaku Kasi Pelayanan Pemerintah Desa Karanganyar, Keluarga Penerima Manfaat (KPM) harus memenuhi kriteria Rumah Tangga Miskin (RTM) dan melihat nilai desil berikut ${ }^{11}$ :

10 Peraturan Menteri Sosial Republik Indonesia Nomor 20 Tahun 2019 tentang Penyaluran Bantuan Pangan Non Tunai.

11 Setyaningsih, Hasil Wawancara Dengan Penulis, pada tanggal 14 Oktober 2019.. 
Jurnal Media Komunikasi Pendidikan Pancasila dan Kewarganegaraan

Volume 2, Nomor 1 April 2020

Tabel 4. Kriteria Desil

(Kelompok Persepuluhan rumah tangga dalam Basis Data Terpadu)

\begin{tabular}{|l|l|}
\hline Tingkat Desil & \multicolumn{1}{c|}{ Keterangan } \\
\hline Desil 1 & $\begin{array}{l}\text { Rumah tangga / individu dengan kondisi kesejahteraan sampai dengan } \\
10 \% \text { terendah }\end{array}$ \\
\hline Desil 2 & $\begin{array}{l}\text { Rumah tangga / individu dengan kondisi kesejahteraan sampai dengan } \\
11 \%-20 \% \text { terendah }\end{array}$ \\
\hline Desil 3 & $\begin{array}{l}\text { Rumah tangga / individu dengan kondisi kesejahteraan sampai dengan } \\
21 \%-30 \% \text { terendah }\end{array}$ \\
\hline Desil 4 & $\begin{array}{l}\text { Rumah tangga / individu dengan kondisi kesejahteraan sampai dengan } \\
31 \%-40 \% \text { terendah }\end{array}$ \\
\hline
\end{tabular}

Sumber : Mengelola Basis Data Terpadu (BDT) Format Verivikasi.

3. Pelaksanaan Program Bantuan Pangan Non Tunai (BPNT) Di Desa

Karanganyar

Kalibening

Banjarnegara

Program Bantuan Pangan Non

Tunai (BPNT) merupakan program transformasi dari program RASTRA untuk memastikan program menjadi lebih tepat sasaran, tepat jumlah, tepat waktu, tepat harga, tepat kualitas, dan tepat administrasi. Program BPNT telah dilaksanakan secara bertahap mulai tahun 2017 dan terus diperluas ke wilayah-wilayah lainnya sampai saat ini. Khusus untuk tahun 2019, Program BPNT akan dilaksanakan di wilayah yang memiliki keterbatasan dari sisi infrastruktur nontunai, sinyal telekomunikasi dan akses geografis, sehingga transformasi program Rastra ke BPNT tuntas di seluruh kabupaten/kota. Ke depannya, program BPNT dapat diintegrasikan dengan program bantuan sosial lainnya melalui sistem perbankan $^{12}$.

Terakhir pada tahun 2017 dengan dasar Perpres No. 63 / Tahun 2017 tentang Penyaluran Bantuan Sosial Secara Non Tunai, RASTRA diganti BPNT. Mensos berharap program ini

12 Tim Pengendalian Pelaksanaan Penyaluran Bantuan Sosial Secara Non Tunai, Pedoman dapat menjadi lebih baik dari program sebelumnya karena KPM sudah tidak dipungut biaya tebus dan diharapkan mampu lebih tepat sasaran.

Kemudian mengenai supply beras, pada tahun 2017 hingga 2018 e-Warong masih mengambil beras langsung dari tengkulak dengan harga yang relatif lebih mahal namun kualitas yang bagus. Namun karena selisih harga dan stok beras di gudang Bulog menumpuk, maka dengan Surat Edaran Menteri Sosial Nomor 01/MS/K/07/2019 tentang perum Bulog, pihaknya bersedia bertugas sebagai penyedia komoditas bantuan pangan non tunai dan Perum Bulog sudah memberikan jaminan beras berkualitas dengan menyalurkan sesuai dengan prinsip 6T. Sehingga pada tahun 2019, supplyberas dalam hal BPNT kembali diserahkan ke Perum Bulog.

Berdasarkan hasil penelitian dapat diketahui bahwa petugas BPNT di Desa Karanganyar Kecamatan Kalibening Kabupaten Banjarnegara melaksanakan program tersebutdengan kurang berpedoman pada Pedoman Program Bantuan Pangan Non Tunai Tahun 2019 dimana BPNT itumempunyai beberapa proses utama dalam pelaksanaan dari BPNT itu sendiri. Adapun mekanisme

Umum Bantuan Pangan Non Tunai 2019, hlm.i. 
dari penyaluran Program BPNT tersebut, yaitu :

1. Penerima BPNT yang telah memiliki KKS tidak langsung datang ke eWarong terdekat untuk melakukan transaksi pembelian bahan pangan menggunakan KKS. Melainkan ada dua orang petugas di desa dan pendamping yang ditugaskan dari Dinas Sosial Kabupaten Banjarnegara, mereka menarik KKS yang ada pada setiap KPM dan mengurus proses penggesekan KKS pada e-Warong yang terdapat di Desa Sirukun. Dikarenakan di Desa Karanganyar belum terdapat eWarong.

2. Kemudian Petugas dari 2 dusun ini menyatukan bukti transaksi yang didapat dari e-Warong dengan Buku Rekening KKS dan kartu KKS yang sebelumnya diminta dari KPM.

3. Setelah itu, kartu akan dibagikan dengan kertas kecil yang diberi nomor urut untuk memudahkan pada saat pengambilan manfaat yang dilaksanakan di gedung Badan Usaha Milik Desa (BUMDES)

4. Lalu para KPM akan mengantri dan menunggu untuk dipanggil berdasarkan nomor antrian yang telah dibagikan sebelumnya. Petugas penyaluran BPNT mendapat data KPM BPNT dari Dinas Sosial.

5. Yang terakhir, KPM pulang dengan membawa $10 \mathrm{Kg}$ beras saja dan KKS mereka akan dikembalikan dengan bukti transaksi penggesekan pada eWarong.

4. Kendala Yang Muncul pada Program Bantuan Pangan Non Tunai Di Desa Karanganyar Kecamatan Kalibening Kabupaten Banjarnegara

Berdasarkan hasil penelitian dapat diketahui bahwa jumlah KPM yang berada di Desa Karanganyanyar Kecamatan Kalibening Kabupaten
Banjarnegara mencapai angka 50,5\% dari jumlah keseluruhan KK yang ada. Hal tersebut menunjukkan bahwa 50,5\% dari masyarakat Desa Karanganyar merupakan KK yang memiliki tingkat kesejahteraan $10 \%$ sampai dengan $30 \%$ terendah. Namun pada kenyataannya, yang penulis temukan dari hasil wawancara dengan perangkat desa terkait dan pengurus RT setempat, warga dengan kesejahteraan sosial yang dapat dibilang cukup mampu masih banyak yang menjadi penerima BPNT. Parahnya, saat ini banyak dijumpai rumah warga yang dapat dibilang permanen dan bagus didepannya tertempel stiker yang bertuliskan "Fakir Miskin" yang merupakan tanda bahwa keluarga yang tinggal didalam rumah itu merupakan penerima dari bantuan sosial baik berupa PKH maupun BPNT.

Kedua, berdasarkan hasil penelitian pada point F1, dapat diketahui bahwa pada tingkat pencapaian indikator 6T, yaitu tepat sasaran, tepatjumlah, tepat harga, tepat waktu, tepat kualitas, dan tepat administrasi. Ditemukan kendala :

1. Ketidak tepatan sasaran, dimana penerima merupakan KK yang tidak memenuhi keriteria KK miskin. Dimana penghasilan tetap perbulannya lebih dari Rp. 500.000 dan memiliki rumah permanen serta sangat layak huni dan gaya hidup yang mencerminkan kesejahteraan sosialnya.

2. Ketidak tepatan harga dan jumlah, karena KPM hanya menerima beras sebanyak $10 \mathrm{Kg}$ dengan harga Rp.10.000 per-Kg. Jika merujuk pada pedoman BPNT maka seharusnya masih ada sisa Rp. 10.000 per-KK dan mereka harusnya menerima $5 \mathrm{Kg}$ beras dan $2 \mathrm{Kg}$ telur.

3. Tidak tepatnya waktu pembagian, karena penyaluran BPNT meskipun jelas satu tahap setiap bulan namun tanggalnya selalu berubah-ubah. Bisa 
jadi bulan pertama pada tanggal 18 kemudian bulan berikutnya dilaksanakan pada tanggal 22.

Selain itu, kendala yang timbul adalah kurangnya sumber daya manusia atau tenaga ahli untuk mengolah data yang tiba-tiba diserahkan oleh BPS ke Dinas Sosial dan beralih dari Data Terpadu Kesejahteraan Sosial menjadi Basis Data Terpadu. Saat program tersebut diserahkan ke pemerintah daerah, bagian pendataan Fakir Miskin kewalahan dengan proses input data. Sehingga masih mengacu pada data sebelumnya, juga masih mendapat kesulitan akses dan penggantian data. Meskipun setiap bulannya ada Bimbingan Teknis (BIMTEK) yang dilaksanakan oleh Dinas Sosial Kabupaten Banjarnegara, namun saat mengusulkan penerima yang baru maupun menghapus penerima lama tetap ditemukan kendala. Karena jika akan melakukan penghapusan $1 \mathrm{KK}$ dari daftar maka harus mencari $1 \mathrm{KK}$ sebagai gantinya, begitupun sebaliknya. Dengan kata lain system penginputan data bersifat kuota, maka harus terjadi substitusi. Kurangnya SDM yang bertugas sebagai operator data dari desa ke kabupaten juga menjadi kendala. Kesalahan data juga sering kali muncul ketika perangkat Desa Karanganyar sudah menginput pembaharuan data penerima, namun data output dari kabupaten yang sampai ke desa dalam bentuk hardfilemasih data lama yang belum diperbaharui.

BDT adalah data terpadu untuk Program Perlindungan Sosial yang dikelola oleh Tim Nasional Percepatan Penanggulangan Kemiskinan (TNP2K). TNP2K ini adalah sebuah sistem yang dapat digunakan untuk perencanaan program dan mengidentifikasi nama dan alamat calon penerima bantuan sosial, baik rumah tangga, keluarga maupun individu berdasarkan pada kriteria- kriteria sosial-ekonomi yang ditetapkan oleh pelaksana program. Fungsi dari BDT ini adalah :

a. Melakukan analisis atau perencanaa data/ program kemiskinan.

Data ini dapat digunakan antara lain bagi instansi pemerintah, lembaga penelitian, lembaga swadaya masyarakat untuk melakukan analisis tentang indikator sosial-ekonomi bagi $40 \%$ masyarakat dengan kondisi sosial-ekonomi terendah. Bagi perencana program Pemerintah (Pusat maupun Daerah), indikator tersebutdapat digunakan untuk merancang program penanggulangan kemiskinan yang relevan, sekaligus memperkirakan anggaran yang dibutuhkan untuk program tersebut.

b. Menetapkan sasaran penerima manfaat program-program perlindungansosial.

c. Ketika instansi pelaksana program penanggulangan kemiskinan atauperlindungan sosial telah menetapkan kriteria kepesertaan program, maka BDT dapat menyediakan data nama dan alamat individu/ keluarga/ rumah tangga bagi instansi pemerintahan yang mengelola program perlindungan sosial. Sebagai contoh sejak tahun 2012 BDT telah menyediakan nama dan alamat penerima manfaat dari Program RASKIN, Jaminan Kesehatan Masyarakat (JAMKESMAS), Beasiswa Miskin, Program Keluarga Harapan (PKH),maupun program lain yang dikelola pemerintah Daerah.

Isi dari BDT itu sendiri memuat informasi sosial-ekonomi dan demografi darisekitar $40 \%$ penduduk di Indonesia yang paling rendah status kesejahteraannya. Cakupan dari 40\% penduduk dengan kondisi sosialekonomi terendah ini ialah sekitar 25 juta rumah tangga atau sekitar 92 juta 
individu. Rumah tangga yang ada dalam BDT ini dapat diurutkan menurut peringkat kesejahteraannya.

Kemudian Dinas Sosial akan menurunkan orang untuk bekerja sebagai Surveyor dan Pendamping dalam pelaksanaan program BPNT. Surveyor bertugas untuk mensurvei apakah bantuan sosial tersebut tepat sasaran atau tidak. Sementara pendamping bertugas untuk membantu KPM pada saat pengambilan manfaat. ${ }^{13}$

Kendala yang terakhir adalah sulitnya membangun mindset masyarakat setempat untuk merasa cukup sejahtera dan tidak mengandalkan bantuan dari pemerintah. Karena pada faktanya yang terjadi, pada data KK yang akan dihapus dari daftar penerima sebelumnya akan di survey terlebih dahulu oleh petugas dari Dinas Sosial. Kemudian saat ditanya apakah mampu tetap memenuhi kebutuhan hidup seharihari jika bantuan tersebut dihentikan, si penerima akan menjawab tidak. Dengan kata lain, KPM tersebut tidak mau mundur. Surveyor atau orang yang ditugaskan untuk menyurvei ke lapangan juga tidak selalu merupakan warga asli desa terkait, jadi kepahaman tentang kondisi setempat sangat minim.

Dengan mindset masyarakat yang demikian justru adanya bantuan sosial malah tidak memandirikan masyarakat, tentunya mereka akan semakin bergantung dan bahkan bangga mendapat bantuan dari pemerintah.

\section{Kesimpulan}

Berdasarkan uraian yang telah dijelaskan dalam hasil penelitian dan pembahasan, dapat diambil kesimpulan sebagai berikut :

1. Pelaksanaan Program Bantuan Pangan Non Tunai di Desa Karanganyar Kecamatan Kalibening

13 Firman, Hasil Wawancara dengan penulis, Pada tanggal 1 September 2019.
Kabupaten Banjarnegarabelum dilaksanakan sesuai dengan Undang Undang Republik Indonesia Nomor 13 Tahun 2011 tentang Penanganan Fakir Miskin dan Peraturan Kementerian Sosial Republik Indonesia Nomor 20 Tahun 2019 tentang Penyaluran Bantuan Pangan Non Tunai serta Pedoman Pelaksanaan Bantuan Pangan Non Tunai Tahun 2019.

2. Dalam proses validasi di tahun 2019 masih terdapat data dari Pusat Data dan Informasi tentang Basis Data Terpadu Penanganan Fakir Miskin yang tidak sesuai dengan kondisi dilapangan sehingga mengakibatkan data tersebut belum tepat sasaran terhadap calon peseta keluarga penerima manfaat.

\section{Saran}

1. Guna mendapatkan data yang valid dan tepat sasaran, data dari Pusdatin Kementerian Sosial Republik Indonesia diharapkan benar - benar dilakukan pengecekan data untuk menghindari duplikasi data dan ketidakbersihan data dari data anomali. Dan pihak BPS diharapkan menugaskan orang yang berintegritas tinggi untuk melakukan survey lapangan sehingga mampu berkoordinasi lebih lanjut untuk penghapusan maupun pengusulan data KPM.

2. Pemerintah diharapkan mampu memberikan sosialisasi guna mengubah mindset masyarakat agar tidak bergantung pada bantuan sosial dari pemerintah.

\section{Daftar Pustaka}

Redaksi Sinar Grafika, "UUD 1945 Hasil Amandemen \& Proses Amandemen UUD 1945 Secara 
Jurnal Media Komunikasi Pendidikan Pancasila dan Kewarganegaraan Volume 2, Nomor 1 April 2020

Lengkap“(Jakarta: Sinar Grafika, 2016).

Ridwan HR, "Hukum Administrasi Negara”, (Jakarta : PT. Raja Grafindo Persada, 2007).

Loekman Soetrisno, "Kemiskinan dan Kesenjangan di Indonesia”, Terj. Awan Setya Dewanta dkk. (Yogyakarta : Aditya Media, 1995).

BULOG, "Sekilas RASKIN", diakses dari

http://www.bulog.co.id/sekilas_ra skin.php, pada tanggal 10 Oktober 2019.

Data Badan Pusat Statistik Kabupaten Banjarnegara Tahun 1996-2017.

Soerjono Soekanto \& Sri Mamudji, "PenelitianHukum Normatif (Suatu Tinjauan Singkat)", (Jakarta: Rajawali Pers, 2001).

Ronny Hanitijo Soemitro, Metode Penelitian Hukum dan Yurimetri, Jakarta : Ghalia, 1994.

J. Supranto, Metode Penelitian Hukum dan Statistik, Jakarta : PT Rineka Cipta, 2003.

Burhan Bungin, Metodologi Penelitian Kualitatif, Jakarta : PT Raja Grafindo Persada 2005.

Peraturan Menteri Sosial Republik Indonesia Nomor 20 Tahun 2019 tentang Penyaluran Bantuan Pangan Non Tunai.

Setyaningsih, Hasil Wawancara Dengan Penulis, pada tanggal 14 Oktober 2019.

Tim Pengendalian Pelaksanaan Penyaluran Bantuan Sosial Secara Non Tunai, Pedoman Umum Bantuan Pangan Non Tunai 2019.

Firman, Hasil Wawancara dengan penulis, Pada tanggal 1 September 2019. 